\title{
Carbon dioxide laser irradiation stimulates mineralization in rat dental pulp cells
}

\author{
Y. Yasuda ${ }^{1}$, E. Ohtomo ${ }^{1}$, T. Tsukuba ${ }^{2}$, K. Okamoto ${ }^{2} \&$ T. Saito ${ }^{1}$ \\ ${ }^{1}$ Division of Clinical Cariology and Endodontology, Department of Oral Rehabilitation, \\ School of Dentistry, Health Sciences University of Hokkaido, Hokkaido, Japan; \\ ${ }^{2}$ Division of Oral Pathopharmacology, Department of Medical and Dental Sciences, \\ Nagasaki University Graduate School of Biomedical Sciences, Nagasaki, Japan
}

Running title: Effect of laser irradiation

Key words: Carbon dioxide laser, heat shock protein 47, mineralization, dental pulp cells,

collagen

Coresponding author: Yoshiyuki Yasuda, DDS, $\mathrm{PhD}$

Division of Clinical Cariology and Endodontology, Department of Oral Rehabilitation, School

of Dentistry, Health Sciences University of Hokkaido, 1757 Kanazawa, Ishikari-Tobetsu,

Hokkaido, 061-0293 Japan. Tel: +81-133-23-2841, Fax: +81-133-23-1423, E-mail address:

yasuda@hoku-iryo-u.ac.jp 


\section{Abstract}

Aim To examine the effect of carbon dioxide laser irradiation on mineralization in dental pulp cells.

Methodology Rat dental pulp cells were irradiated with a carbon dioxide laser at $2 \mathrm{~W}$ output power for 20,40, and $60 \mathrm{~s}$ and were cultured in ascorbic acid and $\beta$-glycerophosphate containing media. Cell viability was examined $24 \mathrm{~h}$ after laser irradiation by a modified MTT assay. Alizarin Red S staining was performed 10 days after laser irradiation. The amounts of secreted collagen from the cells after irradiation were quantified following Sirius Red staining. The expression levels of collagen type I and HSP47, collagen-binding stress protein, were analyzed by real-time PCR. HSP47 protein expression was examined by Western blotting. Statistical analysis was performed using one-way analysis of variance (ANOVA) followed by the Tukey's multiple comparison test.

Results The cell viability was not affected by laser irradiation at $2 \mathrm{~W}$ for up to $40 \mathrm{~s}$. However, it was significantly decreased by $20 \%$ at $60 \mathrm{~s}(\mathrm{p}<0.05)$. The amount of mineralization after 10 days of irradiation at $2 \mathrm{~W}$ for $40 \mathrm{~s}$ was significantly increased in comparison to the other conditions 
$(p<0.05)$. The extracellular collagen production was significantly increased by $73 \%$ on day 2 and $38 \%$ on day 4 after laser irradiation $(\mathrm{p}<0.05)$. Although collagen type I gene expression was not changed by laser irradiation, HSP47 gene and protein expression was induced within $12 \mathrm{~h}$ and 24 $\mathrm{h}$, respectively.

Conclusions These results suggested that carbon dioxide laser irradiation stimulated mineralization in dental pulp cells. The laser irradiation also increased HSP47 expression but not collagen gene expression. 


\section{Introduction}

Reparative dentine forms in the dental pulp in response to various external stimuli such as caries and abrasion (Kamal et al. 1997, Lee et al. 2006). Direct pulp capping with calcium hydroxide has been advocated to accelerate reparative dentine formation on the exposed pulp surface. However, calcium hydroxide is highly alkaline and causes an inflammatory response. In addition, it has not always been clinically highly efficacious in the uniform formation of reparative dentine (Scarano et al. 2003). Recently, the use of mineral trioxide aggregate (MTA) in direct pulp capping has been reported (Aeinehchi et al. 2003, Chacko \& Kurikose 2006). MTA is superior to calcium hydroxide for pulp capping of mechanically exposed human teeth, however, a variety of histological responses were still observed (Caicedo et al. 2006). Furthermore, no data from long-term clinical results are yet available. In an ideal situation, the exposed pulp surface should be covered promptly with reparative dentine and the dental pulp should not demonstrate an inflammatory response.

The application of lasers has expanded into various fields and has also been frequently used in clinical dentistry (Pearson \& Schuckert 2003, Parker 2007). In cultured cells, irradiation by 
low power laser, such as a diode laser, has been reported to accelerate cell differentiation and mineralization in calvarial and dental pulp cells (Ozawa et al. 1998, Ohbayashi et al. 1999, Ueda \& Shimizu 2003). On the other hand, Moritz et al. (1998a, 1998b) reported that the utility of a high power laser, such as a carbon dioxide laser, is useful on exposed pulp surfaces in direct pulp capping experiments. Furthermore, Melcer et al. (1987) observed that a neo-dentine bridge was formed in the pulp tissue after carbon dioxide laser irradiation on teeth, suggesting that this laser is effective in mineralization. However, the mechanism by which carbon dioxide laser irradiation stimulates mineralization in direct pulp capping treatment is not fully elucidated. Laser irradiation may affect the collagen production in dental pulp cells, because the collagenous network plays an important role in mineralization (Linde 1989).

Heat shock proteins (HSPs) are induced by stress from heat and chemical stimuli (Noda et al. 2002). HSPs have been known to suppress the aggregation of denatured protein (Guzhova \& Margulis 2006). They are also constitutively expressed in normal cells, and are associated with important functions such as protein synthesis and intracellular transport (Eisenberg \& Greene 2007). In particular, HSP47 is a collagen-specific molecular chaperone. It specifically binds to 
collagen and plays an essential role in collagen production (Masuda et al. 1994, Koide et al. 2002).

The purpose of this study was to examine the effect of a carbon dioxide laser on mineralization in rat dental pulp cells. Moreover, the amount of extracellular secreted collagen and the HSP47 expression levels were examined to clarify the stimulatory effects of carbon dioxide laser irradiation on mineralization of dental pulp cells. 


\section{Materials and Methods}

\section{Cells and cell culture conditions}

All animal protocols were approved by the Institutional Animal Care and Use Committee of the Health Sciences University of Hokkaido, and experiments were carried out under the control of the University's Guidelines for Animal Experimentation. The dental pulp cells were isolated from incisors of Wistar rats (female, 5 week old) as described previously (Yokose et al. 2000). The cells were cultured in Dulbecco's Modified Eagle Medium (DMEM, Sigma, St. Louis, MI, USA) supplemented with 10\% foetal bovine serum (Sigma), 10,000 U/ml penicillin (Invitrogen, Grand Island, NY, USA), and $10 \mathrm{mg} / \mathrm{mL}$ streptomycin (Invitrogen) at $37^{\circ} \mathrm{C}$ in a humidified atmosphere of $5 \% \mathrm{CO}_{2}$.

\section{Laser irradiation}

$\mathrm{A} \mathrm{CO}_{2}$ laser apparatus (Bel Luxar LX-20SP, Takara, Kyoto, Japan) with a wavelength of 10.6 $\mu \mathrm{m}$ and a power output of $2.0 \mathrm{~W}$ (A4 mode, $10 \mathrm{pps}$, average power output of $0.3 \mathrm{~W}$ ) was used.

Rat dental pulp cells $\left(5 \times 10^{4}\right.$ cells/well) were seeded out in 24 -well plates and cultured for $24 \mathrm{~h}$, and then serum-starved for $24 \mathrm{~h}$. After withdrawal of medium, the cells were irradiated at $2 \mathrm{~W}$ 
output power for 20,40 , and $60 \mathrm{~s}$ using the scanning method as applied in clinical laser irradiation. The tip was moved gradually at a constant rate, avoiding concentrating laser light on one site, and the whole area was irradiated. The laser beam was delivered by a ceramic tip $(0.8$ $\mathrm{mm}$ diameter) with the distance from the tip of the fibre to the cell layer being $2 \mathrm{~cm}$ (irradiation diameter approximately $2 \mathrm{~mm}$ ). The total energy of irradiation time of $40 \mathrm{~s}$ was $382.2 \mathrm{~J} / \mathrm{cm}^{2}$. Irradiated or non-irradiated (control) cells were cultured in DMEM containing $50 \mu \mathrm{g} / \mathrm{ml}$ ascorbic acid (AA, Sigma) and $10 \mathrm{mM} \beta$-glycerophosphate ( $\beta$-GP, Sigma) for 10 days.

\section{Cell viability assay}

Rat dental pulp cells were cultured in DMEM containing $50 \mu \mathrm{g} / \mathrm{mL}$ AA and $10 \mathrm{mM} \beta$-GP for 24 $\mathrm{h}$ after irradiation or non-irradiation (control). Cell viability was determined by a modified MTT assay (WST-8 assay: Dojindo, Kumamoto, Japan), and data are presented as a percentage of viability values seen under control culture conditions. The assay is based on the cleavage of tetrazolium salt WST-8 to formazan by cellular mitochondrial dehydrogenase. The amount of the dye generated by activity of dehydrogenase is directly proportional to the number of living cells. For the WST-8 assay, a $10-\mu$ L quantity of WST- 8 dye solution was added directly to 100 
$\mu \mathrm{L}$ of culture medium per well. The absorbance of the dye was measured at $450 \mathrm{~nm}$ using a Model 680 microplate reader (Bio-Rad, Hercules, CA, USA).

\section{Quantitative Alizarin Red S staining}

Rat dental pulp cells were cultured as before in $50 \mu \mathrm{g} / \mathrm{mL}$ AA and $10 \mathrm{mM} \beta$-GP-containing media for 10 days. Cells were fixed in $70 \%$ ice-cold ethanol for $1 \mathrm{~h}$ and rinsed with distilled water. Cells were stained with $40 \mathrm{mM}$ Alizarin Red S (Sigma), $\mathrm{pH} 4.2$, for 10 min with gentle agitation. Alizarin Red S staining is specific for calcium deposition. Cells were rinsed three times with distilled water and then rinsed with PBS for 15 min. Dye was extracted from fixed cells by treatment with $500 \mu \mathrm{L} 10 \%$ cetylpyridinium chloride (Nakarai Tesque., Kyoto, Japan) for $20 \mathrm{~min}$ with gentle agitation. The absorbance of the extracted dye was measured at $570 \mathrm{~nm}$ using a Model 680 microplate reader. The amount of Alizarin Red S was determined according to an Arizarin Red S standard curve.

\section{Quantitative analysis of extracellular secreted collagen}

The amount of extracellular secreted collagen was measured on day 2 to day 10 using the method described by Ohbayashi et al.(1999). One hundred microlitres of conditioned media 
were dispensed into wells of 96 well plates, and plates were incubated at $37^{\circ} \mathrm{C}$ for $24 \mathrm{~h}$ until dry. After rinsing with distilled water, $0.2 \%$ Sirius Red (Sigma) in saturated picric acid (wt/vol) was placed in each well for $30 \mathrm{~min}$. The plates were washed with $0.5 \% \mathrm{NaOH}$. The eluted stain was then drawn up and down several times in a pipette and placed into a second plate. Absorbance was read at $540 \mathrm{~nm}$ in a Model 680 microplate reader, and the amount of extracellular secreted collagen was estimated from a standard curve.

\section{Real-time PCR}

The mRNA expression of collagen type I, HSP47 and glyceraldehyde 3-phosphate dehydrogenase (GAPDH) was determined by real-time PCR with rat-specific primers. Total RNA was extracted using RNeasy (Qiagen Inc, Chatworth, CA, USA) and was digested with DNase I (Sigma), according to the manufacturer's instructions. Single-strand cDNA was synthesized with SuperScript II reverse transcriptase (Invitrogen) and random primers. Real-time PCR was performed on a volume of $15 \mu \mathrm{L}$ containing $1.5 \mu \mathrm{L}$ (50 ng) of cDNA and 13.5 $\mu \mathrm{L}$ of master mix containing 7.5 $\mu \mathrm{L}$ of mix (SYBR Green PCR Master Mix, Invitrogen), $0.75 \mu \mathrm{L}$ of each primer $(10 \mathrm{pmol} / \mathrm{L})$, and $4.5 \mu \mathrm{L}$ of diethyl pyrocarbonate-treated water using 
an ABI PRISM 7500 Sequence Detection System Thermal Cycler (Applied Biosystems, Foster city, CA, USA).. The sequences of the rat specific primers were as follows: collagen type I, forward 5'-TTGACCCTAACCAAGGATGC-3', reverse 5'-CACCCCTTCTGCGTTGTATT-3'; HSP47, forward 5'-GTGCGCTCCCTCAGTAACTC-3', reverse 5'-CCACATCCTTGGTGACCTCT-3'; Control primers specific for GAPDH were: forward 5'-TCCACCACCCTGTTGCTGTA-3', reverse 5'-ACCACAGTCCATGCCATCAC-3'. The program was set at $50{ }^{\circ} \mathrm{C}$ for $2 \mathrm{~min}$ and $95^{\circ} \mathrm{C}$ for 10 min followed by 40 cycles of denaturation at $95{ }^{\circ} \mathrm{C}$ for $15 \mathrm{~s}$ and annealing at $60{ }^{\circ} \mathrm{C}$ for $60 \mathrm{~s}$. SYBR green fluorescence was monitored after each elongation period. The threshold was set above the non-template control background and within the linear phase of target gene amplification to calculate the cycle number at which the transcript was detected (denoted $\mathrm{C}_{\mathrm{T}}$ ).

Samples were amplified in triplicate, averages were calculated, and differences in $\mathrm{C}_{\mathrm{T}}$ data were evaluated by Sequence Detection Software V1.3. (Applied Biosystems). For each primers set, validation experiments demonstrated that the efficiencies of target and reference gene amplification were approximately equal; the absolute value of the slope of log input amount 
versus $\mathrm{C}_{\mathrm{T}}$ was $<0.1$.For data analysis, we used the comparative $\mathrm{C}_{\mathrm{T}}$ method $\left(\Delta \Delta \mathrm{C}_{\mathrm{T}}\right.$ method)

with the following formula: $\Delta \mathrm{C}_{\mathrm{T}}=\mathrm{C}_{\mathrm{T}}$ (Target) $-\mathrm{C}_{\mathrm{T}}(\mathrm{GAPDH})$. The comparative $\Delta \Delta \mathrm{C}_{\mathrm{T}}$ calculation involved finding the difference between $\Delta \mathrm{C}_{\mathrm{T}}$ of irradiated cells and the mean value of the $\Delta \mathrm{C}_{\mathrm{T}}$ from the control cells. Fold increase in the expression of specific mRNA in irradiated cells compared to control cells was calculated as $2^{-(\Delta \Delta \mathrm{CT})}$. The data are expressed as RQ (relative quantity) and differences are shown in the figures as the expression ratio of the normalized target gene according to the software results.

\section{Western blotting}

For investigating the expression of HSP47 protein in dental pulp cells, immunoblot analysis was performed. The extracts were prepared from irradiated or non-irradiated cells using lysis buffer $[100 \mathrm{mM}$ Tris-HCl (pH 7.2) containing $150 \mathrm{mM} \mathrm{NaCl}, 0.1 \mathrm{mM}$ DTT/EDTA, 0.1\% Triton X-100]. The protein concentrations were determined using protein assay kit (Bio-Rad). Twenty micrograms of protein were loaded onto 10\% SDS-PAGE gel. After electrophoresis, the SDS-PAGE separated proteins were transferred to nitrocellulose membrane at $60 \mathrm{~V}$ for $2 \mathrm{~h}$.

The membrane was blocked with $10 \%$ bovine serum albumin in TBST $[10 \mathrm{mM}$ Tris- $\mathrm{HCl}$ 
(pH8.0), $150 \mathrm{mM} \mathrm{NaCl}, 0.05 \%$ Tween 20] for $30 \mathrm{~min}$, and incubated with a 1:1000 dilution of polyclonal rabbit IgG against human HSP47 (Stressgen, Ann Arbor, MI, USA) in TBST for $1 \mathrm{~h}$. Then, the membrane was incubated with a 1:2,000 dilution of goat anti-rabbit IgG conjugated with horseradish peroxidase (Sigma) for $1 \mathrm{~h}$. Horseradish peroxidase activity was detected using the ECL system (Amersham Biosciences, Piscataway, NJ, USA).

\section{Statistical analysis}

Statistical analysis was performed with data obtained from three independent experiments.

The data are expressed as mean $\pm \mathrm{SD}$ and analysed using one-way analysis of variance (ANOVA) followed by the Tukey's multiple comparison test. Statistical significance was accepted at $p<0.05$. 


\section{Results}

Rat dental pulp cells were irradiated with a carbon dioxide laser at $2 \mathrm{~W}$ output power for 20 , 40, and $60 \mathrm{~s}$. Thereafter, the cell viability was measured $24 \mathrm{~h}$ after irradiation (Fig. 1A). There was no difference in the cell viability between the control and the cells which were irradiated 20 or 40 s. However, it was significantly decreased by $20 \%$ in the cells which were irradiated for $60 \mathrm{~s}$ in comparison to the controls $(\mathrm{p}<0.05)$. Next, the effect of laser irradiation was examined on the mineralization in dental pulp cells. The cells which were irradiated for $40 \mathrm{~s}$ had a clearly increased number and total area of calcified nodules stained by Alizarin Red S (Fig. 1B). In addition, when the mineralization was determined quantitatively on day 10 , the cells with 40 -second irradiation had significantly increased the degree of mineralization in comparison to the other conditions $(\mathrm{p}<0.05)$. However, no significant differences were observed between the controls and the cells with 20 -second or 60 -second irradiation $(\mathrm{p}>0.05$;

Fig. 1C).

Next, the culture media were collected every 2 days up to 10 days and the amount of extracellular secreted collagen was determined quantitatively after Sirius Red staining. The 
amount of secreted collagen significantly increased after laser irradiation in comparison to the controls $73 \%$ and $38 \%$ on day 2 and 4 , respectively (p $<0.05$; Fig. 2). However, there was no difference in comparison to the controls after day 6.

To clarify the mechanism of increased collagen secretion after irradiation, the effect of laser irradiation on the expression of collagen type I and HSP47 was examined by real-time PCR method. There was no significant difference in the expression of the collagen type I gene between the irradiated cells and the controls at any time point $(\mathrm{p}>0.05$; Fig. 3A).. Interestingly, the expression of the HSP47 gene in the irradiated cells was significantly increased compared to the controls by $54 \%, 57 \%$, and $24 \%$ at $12 \mathrm{~h}, 24 \mathrm{~h}$, and $48 \mathrm{~h}$, respectively ( $<<0.05$ ). In addition, Western blot analysis showed that HSP47 protein with a molecular weight of $47 \mathrm{kDa}$ was increased in the cells $24 \mathrm{~h}$ after irradiation compared to that in control cells (Fig. 3B). 


\section{Discussion}

A carbon dioxide laser has a photothermal effect, which is applied when making incisions in soft tissue and obtaining haemostasis. It also has a photochemical effect used in alleviating pain (Posten et al. 2005). Melcer et al. (1987) reported that neo-dentine bridge formation was observed in pulp tissue after carbon dioxide laser irradiation on teeth of dogs and monkeys. This finding indicates that carbon dioxide laser may be useful for the induction of mineralization. The current study showed a decrease of cell viability for irradiation at $2 \mathrm{~W}$ for $60 \mathrm{~s}$ using a carbon dioxide laser. In other words, if the irradiation time is long, then the energy density is increased even with a low power laser and injuries to cells occur. Therefore, the effect of carbon dioxide laser on mineralization, collagen secretion and HSP47 expression was examined under conditions ( $2 \mathrm{~W}, 40 \mathrm{~s})$ that did not injure the cells.

Collagen, which constitutes almost $90 \%$ of the dentine matrix protein, is synthesized by the odontoblasts and secreted into predentine, where collagen molecules are arranged into fibres. These fibres form the collagenous network in which the mineral crystals are deposited (Linde 1989). Furthermore, it has been reported that collagen type I time-dependently stimulates the 
expression of osteopontin and alkaline phosphatase (ALP), while also inducing the differentiation of bone marrow cells into osteoblasts (Mizuno \& Kuboki 2001). The DGEA (Asp-Gly-Glu-Ala) domain of type I collagen binds with integrin on the cellular membrane. Differentiation is thought to be promoted through its binding with integrin (Mizuno et al. 2000). In this study, carbon dioxide laser irradiation significantly increased in the secretion of collagen into culture media on day 2 and 4 . This finding suggests that increased collagen in culture media acted on the integrin of the cells, and mineralization was thus stimulated. Most recently, Lee et al. (2008) reported that heat stress at $42^{\circ} \mathrm{C}$ for 30 min significantly elevated ALP activity on days 7 and 14 in rat pulp cells compared to control groups, revealing the possibility that heat stress generated by laser elevated ALP activity, thereby stimulating mineralization.

HSP47 knockout mice cannot produce collagen with the correct triple helix. Therefore, they die by 11.5 days postcoitus due to apoptosis in various tissues and vascular ruptures because they cannot form collagen fibres and basement membranes (Nagai et al. 2000). In addition, HSP47 expression is induced by thermal stimuli, and its constitutive expression is closely 
coupled with the amount of the collagen matrix. For example, an increase in the HSP47 expression has been reported in pulmonary fibrosis in which there is increased production of collagen (Razzaque et al. 1998). Therefore, HSP47 expression, which has a close relationship with collagen production, was examined. The results clearly showed that the HSP47 gene was induced by laser irradiation within $12 \mathrm{~h}$ and HSP47 protein was induced within $24 \mathrm{~h}$. The observation that the expression level of HSP47 was correlated with the amount of collagen secretion is consistent with the findings of a previous study (Razzaque et al. 1998). Although collagen gene expression was not altered by carbon dioxide laser irradiation, extracellular collagen secretion did increase. Regarding this discrepancy, increased HSP47 production by laser irradiation have led to efficient assembly of procollagen molecules prior to their secretion, thereby promoting extracellular collagen secretion (Lamandé \& Bateman 1999).

To date, the studies of the mechanism of mineralization induction by laser have been conducted using a low power laser. Irradiation by a low power laser on osteoblasts resulted in increased expression of ALP and osteocalcin (Ozawa et al. 1998, Ohbayashi et al. 1999, Ueda \& Shimizu 2003). It has been reported that these increases are one cause of mineralization 
induction. Hamajima et al. (2003) indicated that the gene expression of a bone-inducing factor called osteoglycin increased by 2-fold within $2 \mathrm{~h}$ when MC3T3-E1 osteoblast-like cells were irradiated by a low power laser. These findings indicate that the mechanism of mineralization induction might differ according to the cells, type of laser, and irradiation conditions.

\section{Conclusion}

Carbon dioxide laser irradiation stimulated collagen production and calcified nodules formation on rat dental pulp cells. Furthermore, laser irradiation enhanced HSP47 gene and protein expressions but not type I collagen gene expression. Further study will be needed to elucidate the role of HSP47 on laser-induced mineralization in dental pulp cells. 


\section{Figure Legends}

Figure 1 Effect of laser irradiation on cell viability and mineralization of dental pulp cells. (A)

Cell viability after carbon dioxide laser irradiation at $2 \mathrm{~W}$ for 20,40 and $60 \mathrm{~s}$ was analysed by

a modified MMT assay. (B) After laser irradiation at $2 \mathrm{~W}$ for 20, 40 and $60 \mathrm{~s}$, rat dental pulp

cells were cultured in DMEM containing AA and $\beta$-GP for 10 days. Representative

photographs of Alizarin Red S staining are shown (Original magnification 200x). (C)

Quantification of Alizarin Red S staining. Bar represents the mean \pm SD $(n=3)$. The data were

analysed using one-way ANOVA: * $\mathrm{p}<0.05$ vs. control.

Figure 2 The amount of collagen secreted into the culture media of dental pulp cells. The

dental pulp cells were irradiated at $2 \mathrm{~W}$ for $40 \mathrm{~s}$ and cultured in DMEM supplemented with AA

and $\beta$-GP for 10 days. Conditioned media from control and irradiated cells were collected

every 2 days. The amount of collagen ( $\mu \mathrm{g} / \mathrm{well})$ was measured by the Sirius Red staining

method. Bar represents the mean $\pm \mathrm{SD}(\mathrm{n}=3)$. The data were analysed using one-way ANOVA.

Significantly different from the control at each time point: ${ }^{*} \mathrm{p}<0.05$. Significantly different 
from the day 2: $\# \mathrm{p}<0.05$.

Figure 3 The expression of collagen type I and HSP47 in control and irradiated cells. (A) The dental pulp cells were irradiated at $2 \mathrm{~W}$ for $40 \mathrm{~s}$ and cultured in DMEM supplemented with AA and $\beta$-GP. The mRNA expression of collagen type I and HSP47 was analysed at the indicated time points by real-time PCR. Bar represents the mean $\pm S D(n=3)$. The data were analysed using one-way ANOVA. Significantly different from the control at each time point: ${ }^{*} \mathrm{p}<0.05$. Significantly different from time 0 : \#p $<0.05$. (B) The HSP47 protein expression was examined by Western blotting. 


\section{References}

Aeinehchi M, Eslami B, Ghanbariha M, Saffar AS (2003) Mineral trioxide aggregate (MTA) and calcium hydroxide as pulp-capping agents in human teeth: a preliminary report. International Endodontic Journal 36, 225-31.

Caicedo R, Abbott PV, Alongi DJ, Alarcon MY (2006) Clinical, radiographic and histological analysis of the effects of mineral trioxide aggregate used in direct pulp capping and pulpotomies of primary teeth. Australian Dental Journal 51, 297-305.

Chacko V, Kurikose S (2006) Human pulpal response to mineral trioxide aggregate (MTA): a histologic study. Journal of Clinical Pediatric Dentistry 30, 203-9.

Eisenberg E, Greene LE (2007) Multiple roles of auxilin and hsc70 in clathrin-mediated endocytosis. Traffic 8, 640-6.

Guzhova I, Margulis B (2006) Hsp70 chaperone as a survival factor in cell pathology. International Review of Cytology 254, 101-49.

Hamajima S, Hiratsuka K, Kiyama-Kishikawa M et al. (2003) Effect of low-level laser irradiation on osteoglycin gene expression in osteoblasts. Lasers in Medical Science 18, 78-82. 
Kamal AM, Okiji T, Kawashima N, Suda H (1997) Defense responses of dentin/pulp complex to experimentally induced caries in rat molars: an immunohistochemical study on kinetics of pulpal Ia antigen-expressing cells and macrophages. Journal of Endodontics 23, 115-20.

Koide T, Takahara Y, Asada S, Nagata K (2002) Xaa-Arg-Gly triplets in the collagen triple helix are dominant binding sites for the molecular chaperone HSP47. Journal of Biological Chemistry 277, 6178-82.

Lamandé SR, Bateman JF (1999) Procollagen folding and assembly: the role of endoplasmic reticulum enzymes and molecular chaperones. Seminars in Cell \& Developmental Biology 10, $455-64$.

Lee MW, Muramatsu T, Uekusa T, Lee JH, Shimono M (2008) Heat stress induces alkaline phosphatase activity and heat shock protein 25 expression in cultured pulp cells. International Endodontic Journal 41, 158-62.

Lee YL, Liu J, Clarkson BH, Lin CP, Godovikova V, Ritchie HH (2006) Dentin-pulp complex responses to carious lesions. Caries Research 40, 256-64.

Linde A (1989) Dentin matrix proteins: composition and possible functions in calcification. 
Anatomical Record 224, 154-66.

Masuda H, Fukumoto M, Hirayoshi K, Nagata K (1994) Coexpression of the collagen-binding stress protein HSP47 gene and the $\alpha$ 1(I) and $\alpha$ 1(III) collagen genes in carbon tetrachloride-induced rat liver fibrosis. Journal of Clinical Investigation 94, 2481-8.

Melcer J, Chaumette MT, Melcer F (1987) Dental pulp exposed to the $\mathrm{CO}_{2}$ laser beam. Lasers in Surgery and Medicine 7, 347-52.

Mizuno M, Fujisawa R, Kuboki Y (2000) Type I collagen-induced osteoblastic differentiation of bone-marrow cells mediated by collagen- $\alpha 2 \beta 1$ integrin interaction. Journal of Cellular Physiology 184, 207-13.

Mizuno M, Kuboki Y (2001) Osteoblast-related gene expression of bone marrow cells during the osteoblastic differentiation induced by type I collagen. Journal of Biochemistry 129, 133-8. Moritz A, Schoop U, Goharkhay K, Sperr W (1998a) The $\mathrm{CO}_{2}$ laser as an aid in direct pulp capping. Journal of Endodontics 24, 248-51.

Moritz A, Schoop U, Goharkhay K, Sperr W (1998b) Advantages of a pulsed $\mathrm{CO}_{2}$ laser in direct pulp capping: a long-term in vivo study. Lasers in Surgery and Medicine 22, 288-93. 
Nagai N, Hosokawa M, Itohara S et al. (2000) Embryonic lethality of molecular chaperone hsp47 knockout mice is associated with defects in collagen biosynthesis. Journal of Cell Biology 150, 1499-506.

Noda M, Wataha JC, Kaga M, Lockwood PE, Volkmann KR, Sano H (2002) Components of dentinal adhesives modulate heat shock protein 72 expression in heat-stressed THP-1 human monocytes at sublethal concentrations. Journal of Dental Research 81, 265-9.

Ohbayashi E, Matsushima K, Hosoya S, Abiko Y, Yamazaki M (1999) Stimulatory effect of laser irradiation on calcified nodule formation in human dental pulp fibroblasts. Journal of Endodontics 25, 30-3.

Ozawa Y, Shimizu N, Kariya G, Abiko Y (1998) Low-energy laser irradiation stimulates bone nodule formation at early stages of cell culture in rat calvarial cells. Bone 22, 347-54.

Parker S (2007) Low-level laser use in dentistry. British Dental Journal 202, 131-8.

Pearson GJ, Schuckert KH (2003) The role of lasers in dentistry: present and future. Dental Update 30, 70-4.

Posten W, Wrone DA, Dover JS, Arndt KA, Silapunt S, Alam M (2005) Low-level laser 
therapy for wound healing: mechanism and efficacy. Dermatologic Surgery 31, 334-40.

Razzaque MS, Hossain MA, Kohno S, Taguchi T (1998) Bleomycin-induced pulmonary fibrosis in rat is associated with increased expression of collagen-binding heat shock protein (HSP) 47 Virchows Archiv 432, 455-60.

Scarano A, Manzon L, Di Giorgio R, Orsini G, Tripodi D, Piattelli A (2003) Direct capping with four different materials in humans: histological analysis of odontoblast activity. Journal of Endodontics 29, 729-34.

Ueda Y, Shimizu N (2003) Effects of pulse frequency of low-level laser therapy (LLLT) on bone nodule formation in rat calvarial cells. Journal of Clinical Laser Medicine and Surgery 21, 271-7.

Yokose S, Kadokura H, Tajima Y et al. (2000) Establishment and characterization of a culture system for enzymatically released rat dental pulp cells. Calcified Tissue International 66, $139-44$. 
Fig. 1

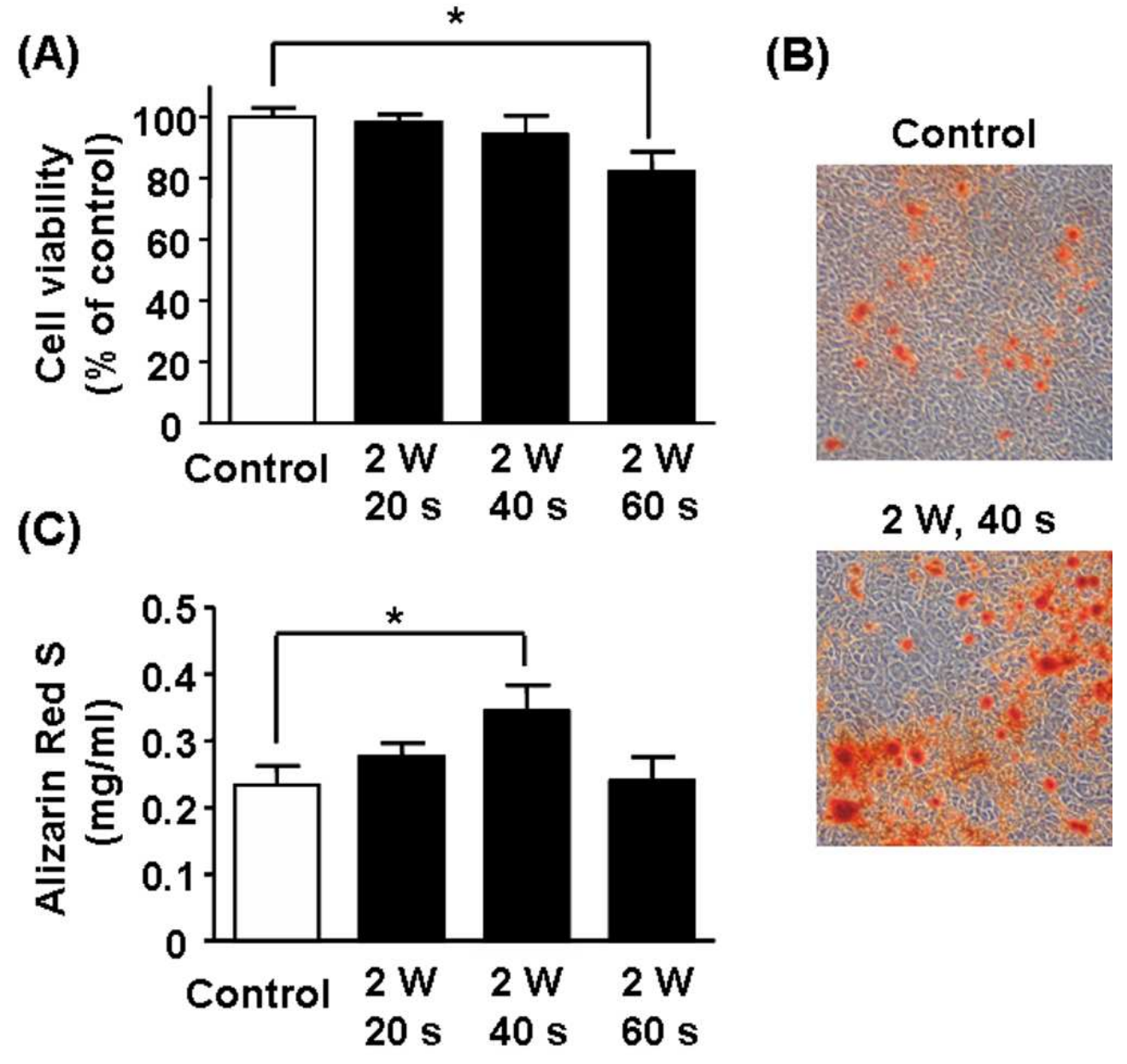

$130 \times 132 \mathrm{~mm}(200 \times 200 \mathrm{DPI})$ 
Fig. 2

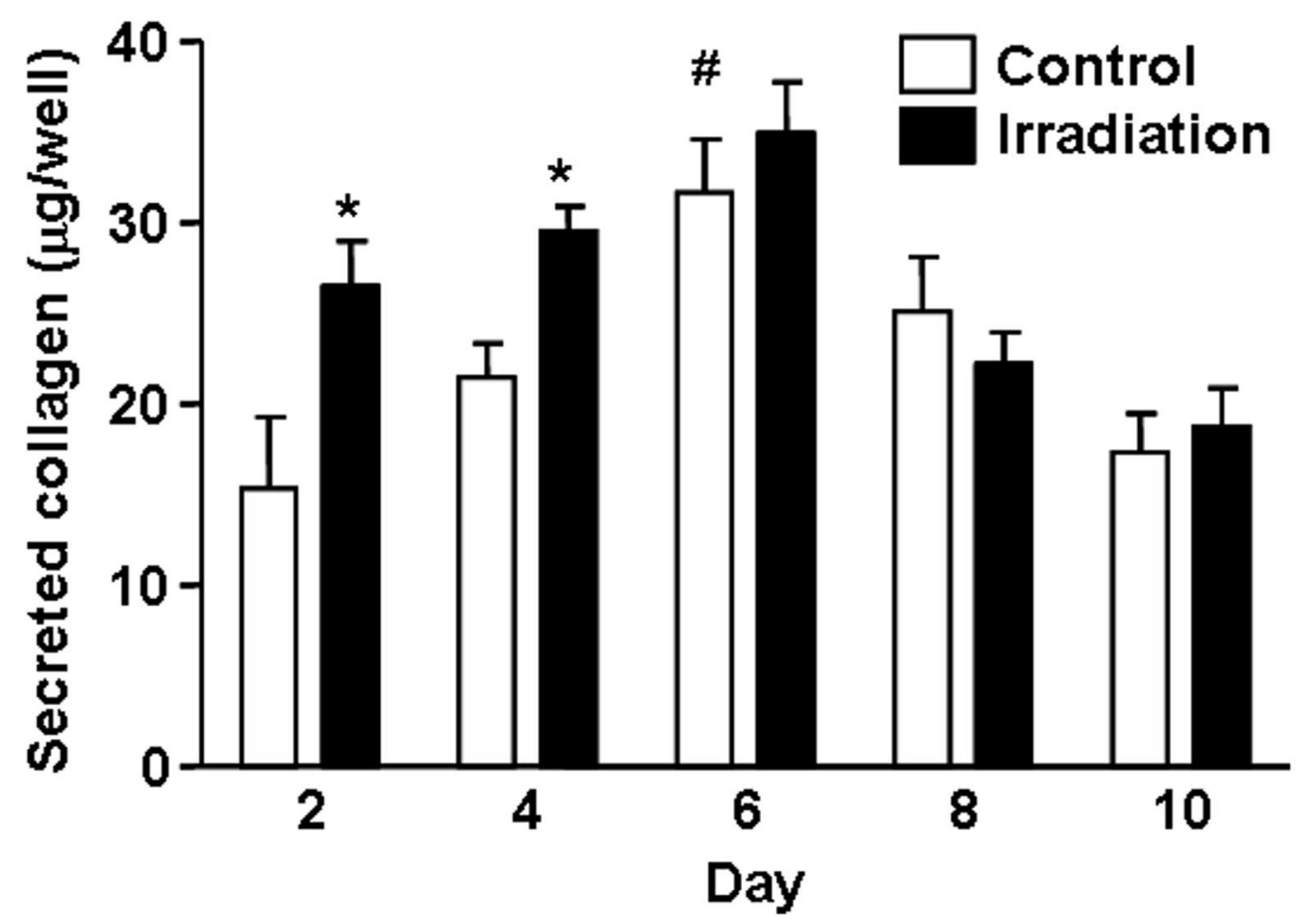

$80 \times 68 \mathrm{~mm}(500 \times 500$ DPI $)$ 
Fig. 3
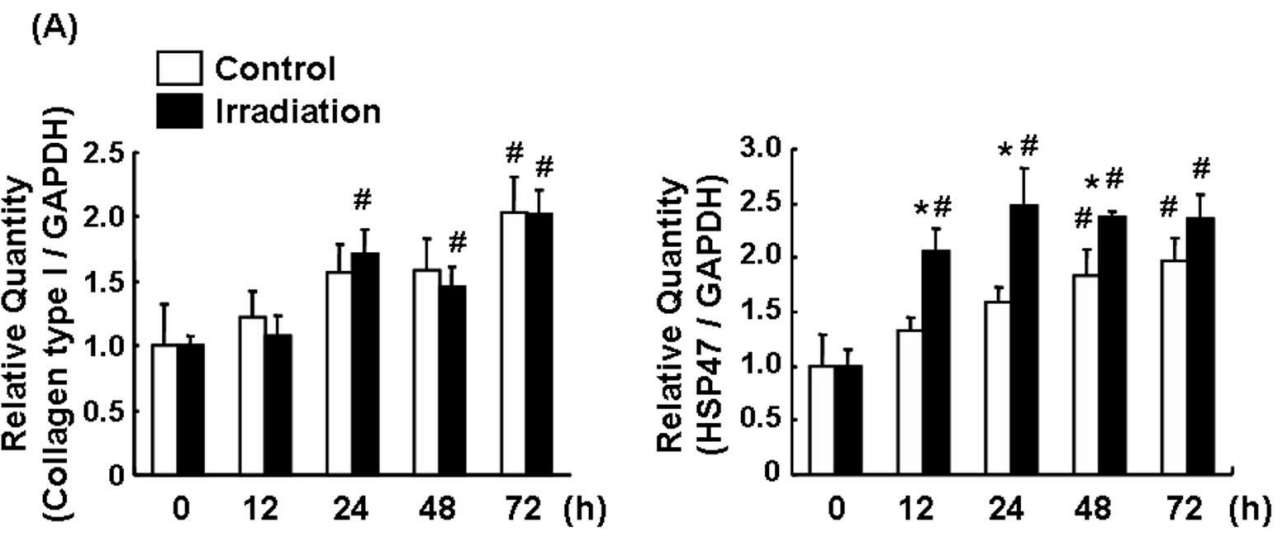

(B)

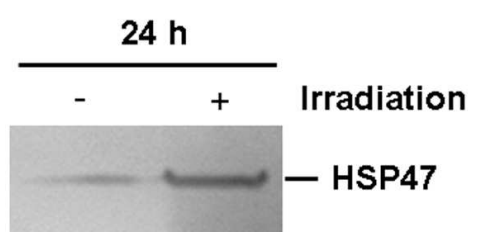

$160 \times 111 \mathrm{~mm}(500 \times 500 \mathrm{DPI})$ 